\title{
Effects of $\boldsymbol{\gamma}$-aminobutyric acid on skate retinal horizontal cells: Evidence for an electrogenic uptake mechanism
}

\author{
(retina/neurotransmitters/vision/ $\gamma$-aminobutyric acid transport)
}

\author{
Robert Paul Malchow* ${ }^{*} \ddagger$ AND HaRris RIPPS $* \dagger \S$ \\ ${ }^{*}$ Lions of Illinois Eye Research Institute, Department of Ophthalmology, and the ${ }^{\S}$ Department of Anatomy-Cell Biology, University of Illinois College of \\ Medicine, Chicago, IL 60612; and the ${ }^{\dagger}$ Marine Biological Laboratory, Woods Hole, MA 02543
}

Communicated by John E. Dowling, July 23, 1990

\begin{abstract}
In the retinae of many vertebrates, there are classes of horizontal cell that probably utilize $\boldsymbol{\gamma}$-aminobutyric acid (GABA) as a neurotransmitter. As with other amino acid transmitter agents, the postsynaptic action of GABA is thought to be terminated by uptake into neurons and glia surrounding the release site. The present study examined whether an uptake system for GABA could be detected in isolated skate horizontal cells by means of electrophysiological methods. Pressure ejection of GABA onto voltage-clamped horizontal cells produced an inward current that showed no sign of desensitization regardless of the GABA concentration. The dose-response relationship followed simple Michaelis-Menten kinetics, with a half-maximal response elicited at $\approx 110 \mu \mathrm{M}$. Nipecotic acid produced a similar current and reduced the responses to GABA when introduced in the bath solution prior to the GABA pulse. On the other hand, application of $500 \mu \mathrm{M}$ muscimol or $1 \mathrm{mM}$ baclofen, GABA $_{A}$ and $G A B A_{B}$ receptor agonists, respectively, were completely without effect. The GABA-induced current was not blocked by superfusion with $500 \mu \mathrm{M}$ bicuculline, 500 $\mu \mathrm{M}$ picrotoxin, or $\mathbf{5 0 0} \boldsymbol{\mu M}$ phaclofen. However, the responses to GABA were abolished when the cells were superfused in Ringer's solution in which choline or lithium had been substituted for sodium, and were reduced when the extracellular chloride concentration was decreased from $266 \mathrm{mM}$ to $16 \mathrm{mM}$. Current-voltage data showed a maximal response to GABA when the cells were held at or below their resting potential. At more depolarized levels, the inward current became progressively smaller until, near $+50 \mathrm{mV}$, it could no longer be detected; over the range tested $(-90$ to $+50 \mathrm{mV})$, the response never reversed into an outward current. These findings suggest that the GABA-induced currents in skate horizontal cells are mediated by an electrogenic uptake mechanism.
\end{abstract}

There is abundant evidence that $\gamma$-aminobutyric acid (GABA), generally considered one of the main inhibitory neurotransmitters of the central nervous system, is involved in signal transmission between neurons in the vertebrate retina (1). From studies dealing primarily with the uptake and release of radiolabeled GABA, it appears likely that in many species there are particular types of horizontal cell that use GABA to mediate lateral interactions in the distal retina (2). The apparent absence of degradative enzymes in the extracellular space of GABAergic neurons (3) suggests that synaptic activity is terminated either by uptake into neighboring glial cells or by reuptake of GABA into the nerve terminals from which it is released.

In the all-rod retina of skate, horizontal cells exhibit immunoreactivity to antibodies directed against GABA (4) and against its rate-limiting synthetic enzyme, glutamic acid decarboxylase $(4,5)$, suggesting that these cells not only contain GABA but are capable also of its synthesis. How-

The publication costs of this article were defrayed in part by page charge payment. This article must therefore be hereby marked "advertisement" in accordance with 18 U.S.C. $\$ 1734$ solely to indicate this fact. ever, to our knowledge, there is no information on the mechanism by which GABA is released from skate horizontal cells, nor is it known to what extent the horizontal cell participates in termination of the neurotransmitter's action.

The results of autoradiographic studies on the cellular localization of exogenously applied $\left[{ }^{3} \mathrm{H}\right] \mathrm{GABA}$ suggest that uptake is almost exclusively within the radial glia (Muller cells) of the skate retina $(6,7)$. However, intracellular recordings obtained both in situ (8) and from isolated cells (9) indicate that skate horizontal cells are depolarized by GABA. This depolarizing response might be mediated by an electrogenic uptake mechanism for GABA or, alternatively, it could reflect activation of ligand-gated conductances by $\mathrm{GABA}_{A}$ or $\mathrm{GABA}_{\mathrm{B}}$ receptors.

To distinguish between these possibilities, we studied the effects of GABA and related pharmacological agents on the membrane currents of isolated skate horizontal cells under voltage clamp. The results presented here provide evidence that the external horizontal cells of skate transport GABA by means of an electrogenic sodium-dependent mechanism. Portions of this research have appeared in abstract form (10, $11)$.

\section{MATERIALS AND METHODS}

Cell Dissociation. Skate (Raja erinacea and Raja ocellata) were anesthetized with $0.02 \%$ Tricaine (MS 222, Sigma) and pithed. After enucleation, the anterior portion of the eye was excised and the remaining eyecup was cut into smaller pieces and incubated for $15 \mathrm{~min}$ in $20 \mathrm{ml}$ of an elasmobranch Ringer's solution containing papain $(5125$, Calbiochem; $2 \mathrm{mg} / \mathrm{ml})$ and L-cysteine $(1 \mathrm{mg} / \mathrm{ml})$; the $\mathrm{pH}$ was titrated to 7.6 with $\mathrm{NaOH}$. Elasmobranch Ringer's solution was composed of $250 \mathrm{mM}$

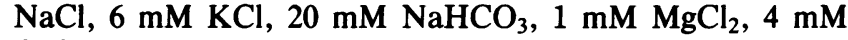
$\mathrm{CaCl}_{2}, 0.2 \mathrm{mM} \mathrm{NaH} \mathrm{PO}_{4}, 360 \mathrm{mM}$ urea, $10 \mathrm{mM}$ glucose, and $5 \mathrm{mM}$ Hepes, adjusted to $\mathrm{pH} 7.6$ with $\mathrm{NaOH}$. Pieces of neural retina were separated from the eyecup and immersed under constant agitation for $60-75 \mathrm{~min}$ in $20 \mathrm{ml}$ of freshly piepared papain-containing Ringer's solution. The tissue was rinsed a minimum of five times with a modified Leibovitz culture medium (L-15, GIBCO), supplemented with $102.7 \mathrm{mM} \mathrm{NaCl}$, $350 \mathrm{mM}$ urea, $5 \mathrm{mM}$ glucose, and $20 \mathrm{mM}$ Hepes, titrated to pH 7.6 with $\mathrm{NaOH} ; 1 \mathrm{ml}$ of an antibiotic-antimycotic mixture containing 5000 units of penicillin and $5 \mathrm{mg}$ of streptomycin (600-5070, GIBCO) was added to each $250 \mathrm{ml}$ of solution. Dissociated cells were obtained by triturating the retinae in 1 $\mathrm{ml}$ of medium using a flame-polished Pasteur pipette, were plated onto plastic culture dishes containing $2 \mathrm{ml}$ of the modified culture medium, and were stored up to 5 days at

Abbreviation: GABA, $\gamma$-aminobutyric acid.

¥To whom reprint requests should be addressed at: Department of Ophthalmology, University of Illinois College of Medicine, 1855 West Taylor Street, Chicago, IL 60612. 
$15^{\circ} \mathrm{C}$. Prior to each experiment, the incubation medium was replaced with the standard Ringer's solution.

Recording Procedures. Electrical responses were obtained exclusively from the large external horizontal cells of the skate retina (12) by using the whole-cell version of the patch-clamp recording technique (13). Pipettes were pulled from Kovar capillary tubing (internal diameter, $1.15 \mathrm{~mm}$, and outer diameter, $1.65 \mathrm{~mm}$ ) and were used without flame polishing; they typically had tip diameters of 2-4 $\mu \mathrm{m}$ and resistances ranging from 1.5 to $4.5 \mathrm{M} \Omega$ when filled with a solution containing $204 \mathrm{mM} \mathrm{KCl}, 1 \mathrm{mM} \mathrm{CaCl}_{2}, 11 \mathrm{mM}$ EGTA, $2 \mathrm{mM} \mathrm{MgCl}, 2 \mathrm{mM} \mathrm{MgATP}$, and $10 \mathrm{mM}$ Hepes, adjusted to pH 7.6 with $\mathrm{KOH}$. The electrodes were connected by a "chlorided" silver wire to a List EPC7 patch-clamp amplifier modified to increase by a factor of 2 the range of capacitance compensation (Medical Systems, New York). G $\Omega$ seals formed readily on the horizontal cells, and the seal was broken after $30 \mathrm{sec}$ with light suction to establish a whole-cell recording configuration; $10-\mathrm{mV}$ test pulses were applied and adjustments were made to compensate for the series resistance of the electrode and cell membrane capacitance. Series resistances averaged $6.56 \pm 2.97 \mathrm{M} \Omega(\mathrm{SD} ; n=75)$; the resistance compensation control on the List amplifier was typically set to $85-90 \%(85 \pm 6.8 \%, n=75)$ to minimize voltage error introduced by the series resistance. In previous experiments we tested the fidelity of the voltage clamp under these conditions by using a second pipette to measure the actual voltage change in the cells; with the electrodes separated by $50-70 \mu \mathrm{m}$, the voltage change was $92-97 \%$ of the command voltage (12). The average capacitance of the cells was found to be $151.2 \pm 44 \mathrm{pF}(n=75)$, and resting potentials averaged $-71 \pm 10.5 \mathrm{mV}$ for 38 cells in which this parameter was measured. The clamp procedure was controlled using a commercially available program (pClamp, version 5; Axon Instruments, Burlingame, CA) run on an IBM AT computer equipped with the $40-\mathrm{kHz}$ version of the Labmaster analog interface (Scientific Solutions, Solon, $\mathrm{OH}$ ). Responses were low-pass-filtered at $500 \mathrm{~Hz}$ and stored on a video cassette recorder after conversion through a PCM recording adaptor (Vetter, Rebersburg, PA).

Drug Application. Drugs were delivered either by pressure ejection from pipettes (tip diameter, $2-4 \mu \mathrm{m}$ ) placed within 50 $\mu \mathrm{m}$ of the cell or by superfusion of the chamber. To minimize the volume of solution bathing the cells, they were enclosed within a U-shaped glass chamber (vol, $110 \mu \mathrm{l})$; the solution entered at one end through a glass capillary (flow rate, 2-5 $\mathrm{ml} / \mathrm{min}$ ) and was removed at the other through a second capillary connected to suction. Pressure ejection of compounds was accomplished using a Picospritzer II (General Valve, Fairfield, NJ); a minimum of two pipettes was employed in any given experiment, one of which always contained a control solution to ensure that the observed responses to the test drugs were not the result of pressure artifacts. Drugs were prepared in normal Ringer's solution except when cells were bathed in Ringer's containing low sodium or low chloride solutions; in these cases, GABA was mixed in the low sodium or chloride solution, and the control pipette was filled with a similar solution lacking GABA. To examine the effects of lowered extracellular sodium, we substituted choline or lithium for sodium, and the Ringer's solution was prepared without the addition of sodium bicarbonate. All chemicals were obtained from Sigma, with the exception of baclofen, which was a gift of CIBA-Geigy Corp., choline hydroxide (Aldrich), bicuculline methylchloride and phaclofen (Tocris Neuramin, Essex, U.K.), and 4-aminopyridine (Pfaltz \& Bauer).

\section{RESULTS}

Currents Induced by GABA and GABA Analogues. Fig. 1 illustrates results obtained from three cells voltage-clamped


Fig. 1. Membrane currents recorded from three external horizontal cells in response to pressure ejection of GABA, muscimol, baclofen, and nipecotic acid; the cells were superfused with normal Ringer's solution and voltage-clamped at $-70 \mathrm{mV}$. (A) Responses from one cell to $500 \mu \mathrm{M} \mathrm{GABA}$ and $500 \mu \mathrm{M}$ muscimol. A large inward current was elicited by the application of GABA, whereas muscimol was completely without effect; similar results were obtained from three additional cells. $(B)$ Responses from another horizontal cell to $500 \mu \mathrm{M}$ GABA and $1 \mathrm{mM}(-)$-baclofen. The inward current seen in response to GABA was not mimicked even by this high concentration of baclofen; four other cells gave similar results. $(C)$ In a third horizontal cell, $1 \mathrm{mM}$ nipecotic acid produced an inward current similar to that observed for GABA; pressure ejection of Ringer's solution alone was without effect. The results with nipecotic acid were replicated on six other cells. Lines above traces indicate the duration of drug application. ( $A$ and $C$ ) Sampled every $30 \mathrm{msec}$. (B) Sampled every $10 \mathrm{msec}$.

at $-70 \mathrm{mV}$. Fig. $1 A$ and $B$ shows the inward currents produced by pressure pulses of $500 \mu \mathrm{M} \mathrm{GABA}$; after reaching a peak of $300-400 \mathrm{pA}$, the currents decayed to baseline several seconds after the drug application had ceased. The recordings also show that neither $500 \mu \mathrm{M}$ muscimol, a potent agonist at $\mathrm{GABA}_{\mathrm{A}}$ receptor sites (14), nor $1 \mathrm{mM}(-)$-baclofen, a GABA $A_{B}$ agonist (15), had any effect on these cells. On the other hand, nipecotic acid, an agent known to interact with uptake sites for GABA (16), initiated a current similar to that produced by GABA (Fig. $1 C$ ). In separate experiments (results not shown), we found that nipecotic acid, when delivered in the superfusate bathing the cells, reduced the responses to GABA in a dose-dependent fashion. In addition, measurements of input impedance (17) showed no significant change as a consequence of the application of GABA or nipecotic acid (data not shown).

Effects of GABA $_{A}$ and GABA $_{B}$ Antagonists. Attempts to block the GABA-induced currents with compounds known to inhibit the actions of $\mathrm{GABA}$ at $\mathrm{GABA}_{\mathrm{A}}$ and $\mathrm{GABA} \mathrm{A}_{\mathrm{B}}$ receptor sites were unsuccessful. Fig. $2 A$ illustrates the results obtained with the GABA $A_{A}$ antagonists bicuculline (18) and picrotoxin (19). The top trace shows the response elicited by a pulse of $500 \mu \mathrm{M}$ GABA delivered while the cell was superfused with normal Ringer's solution. The next two traces show that the GABA-induced response is not signifi- 
cantly reduced by bathing the cell for 2 min in Ringer's solution containing $500 \mu \mathrm{M}$ bicuculline or after a subsequent 2 -min period in $500 \mu \mathrm{M}$ picrotoxin. The recordings from another cell (Fig. $2 B$ ) show that $500 \mu \mathrm{M}$ phaclofen, which blocks the effects of GABA at $\mathrm{GABA}_{\mathrm{B}}$ receptor sites (20), was also ineffective in suppressing the response of skate horizontal cells to GABA.

Ionic Dependence of the GABA Response. The electrogenic uptake of GABA into neurons and glia usually requires the presence of extracellular sodium and chloride; a 2:1:1 stoichiometry of $\mathrm{Na}^{+} / \mathrm{Cl}^{-} / \mathrm{GABA}$ has been reported $(21,22)$. The effects of superfusing horizontal cells in which these ions had been removed or markedly lowered are illustrated in Fig. 2. Replacing all of the sodium chloride in the Ringer's solution with either choline chloride (Fig. $2 A$ ) or lithium chloride (Fig. $2 B$ ) virtually abolished the responses to GABA. Similarly, substituting sodium isethionate for sodium chloride, thus lowering the extracellular chloride concentration from $266 \mathrm{mM}$ to $16 \mathrm{mM}$, also markedly reduced the response of the horizontal cells to GABA (Fig. $2 C$ ). In each of the foregoing experiments, the GABA-induced currents returned to control levels when the superfusate was switched back to the normal Ringer's solution (bottom traces of Fig. 2).

Current-Voltage Relationship. To test the voltage dependence of the GABA-induced current responses, voltagegated currents were minimized by bathing the cells in a Ringer's solution containing $1 \mu \mathrm{M}$ tetrodotoxin, $10 \mathrm{mM}$ 4-aminopyridine, $4 \mathrm{mM}$ cobalt chloride, $10 \mathrm{mM}$ cesium chloride, and $25 \mathrm{mM}$ tetraethylammonium chloride. The membrane voltage was stepped to a new level and held at this potential for at least $10 \mathrm{sec}$ to allow any residual voltagedependent currents to stabilize, at which time a pressure pulse of $500 \mu \mathrm{M}$ GABA was delivered from a nearby pipette.
Fig. $3 A$ shows the current responses from one cell clamped at several different voltage levels ranging from -70 to +50 $\mathrm{mV}$. The inward current associated with GABA was largest when the cell was held at or below its resting potential [typically $-70 \mathrm{mV}(17)$ ] and became progressively smaller as the voltage was stepped to more positive levels. However, even when depolarized to $+50 \mathrm{mV}$, there was no indication of a reversal into an outward current. Similar results were obtained when the cells were bathed in normal Ringer's solution.

The current-voltage relationship for this cell, illustrated in Fig. $3 B$, again points up the fact that the GABA-mediated responses did not reverse polarity for the range of potentials extending from $-90 \mathrm{mV}$ to $+50 \mathrm{mV}$. At potentials exceeding $+50 \mathrm{mV}$, the responses to GABA could not be adequately resolved due to the presence of a large slowly developing outward current induced in horizontal cells in this voltage range (23). Thus, the value at which the GABA current becomes zero is difficult to determine precisely, and we cannot conclude with certainty that the response to GABA never reversed polarity. Nevertheless, in the cells from which recordings could be obtained at voltages up to +70 $\mathrm{mV}$, no sign of current reversal was observed, nor would it be expected for an electrogenic carrier mechanism under the present recording conditions (i.e., using intracellular pipettes that contain neither $\mathrm{Na}^{+}$nor GABA).

Concentration Dependence of the GABA-Mediated Current. The dose-response curve for GABA was determined by superfusing the cells with Ringer's solution containing various concentrations of GABA; usually four concentrations were tested on each cell. As shown by the results in Fig. 4A, the responses to GABA were characterized by an inward current that reached a maximum and remained at that level
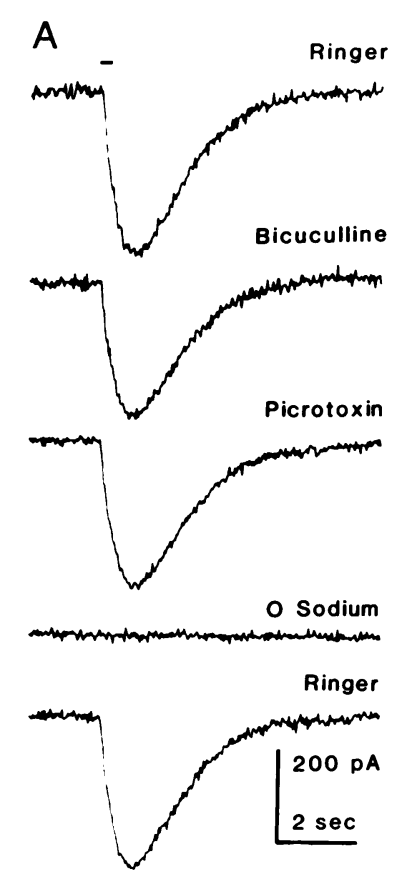

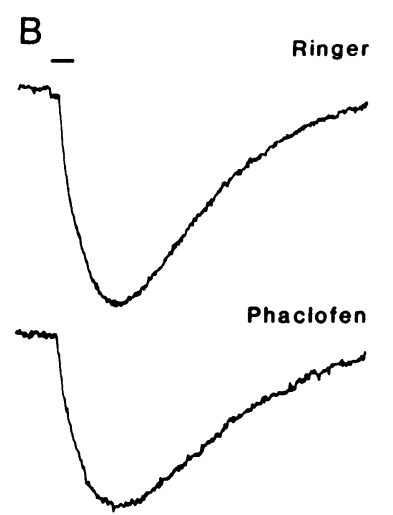

O Sodium

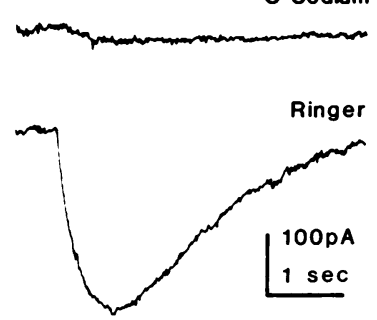

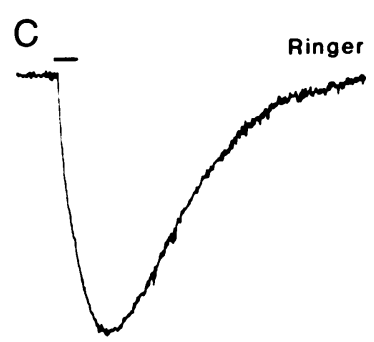
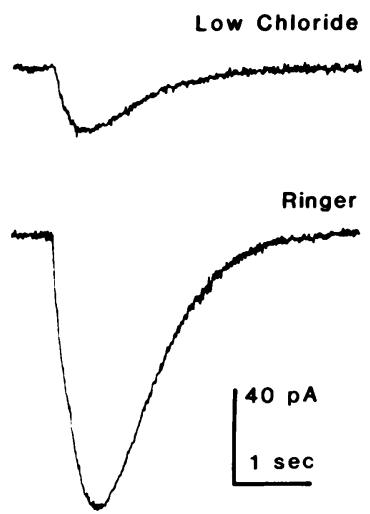

Fig. 2. (A) Responses to GABA pulses ( $300 \mathrm{msec}$ ) during superfusion of bicuculline, picrotoxin, and low sodium. The GABA-induced current seen in normal Ringer's solution was not significantly affected by $500 \mu \mathrm{M}$ bicuculline or by $500 \mu \mathrm{M}$ picrotoxin, but it was completely abolished when the superfusate was switched to one in which all sodium chloride had been replaced with choline chloride ( 0 sodium). Upon return to normal Ringer's solution (final trace), the response to GABA was restored. The line above the top trace indicates the duration of the $500 \mu \mathrm{M}$ GABA pulse. $(B)$ The effects of phaclofen and substitution of lithium for sodium on the responses of an external horizontal cell to $500 \mu \mathrm{M} G A B A$. The $\mathrm{GABA}_{\mathrm{B}}$ antagonist phaclofen had relatively little effect on the response to GABA, whereas superfusing the cell in the low-sodium Ringer's solution markedly reduced the GABA-induced current. The return to normal Ringer's solution restored the response to GABA. Similar results were obtained from four additional horizontal cells. $(C)$ Superfusion with low-chloride Ringer's solution reduced the response of skate horizontal cells to GABA. Responses are from a single horizontal cell to pressure application of $500 \mu \mathrm{M}$ GABA in normal Ringer's solution (top and bottom traces) and in low-chloride Ringer's solution (prepared by substituting all of the sodium chloride with sodium isethionate). Two other cells gave similar results. $(A)$ Sampled every $30 \mathrm{msec}$. $(B$ and $C$ ) Sampled every $10 \mathrm{msec}$. 

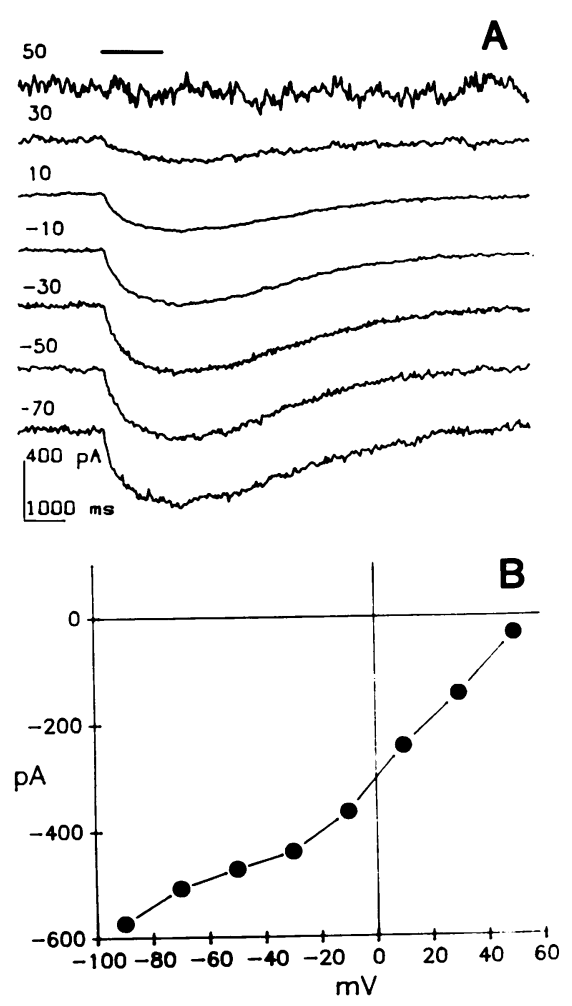

Fig. 3. Current-voltage relation for the GABA-induced current; cells were bathed in a Ringer's solution containing $1 \mu \mathrm{M}$ tetrodotoxin, $10 \mathrm{mM}$ 4-aminopyridine, $4 \mathrm{mM}$ cobalt chloride, $10 \mathrm{mM}$ cesium chloride, and $25 \mathrm{mM}$ tetraethylammonium chloride. $(A)$ Responses from a single horizontal cell to 1.75 -sec pressure application of 500 $\mu M$ GABA from a nearby pipette with the cell held at the voltages indicated. The cell was held at the new potential for at least $10 \mathrm{sec}$ prior to the application of GABA. For each trace, the GABA-induced current was subtracted from the response to voltage alone, thereby eliminating contributions from residual voltage-activated currents. Line above traces represents timing of GABA pulse. (B) Currentvoltage profile for the same cell. The response to GABA is maximal at negative potentials, becomes progressively smaller with increasing depolarization from the holding level of $-70 \mathrm{mV}$, and is barely detectable when the voltage is stepped to $+50 \mathrm{mV}$. Similar results were obtained from five other external horizontal cells. Data were sampled every $10 \mathrm{msec}$.

for as long as the drug was applied. This type of response is unlike that elicited by activation of $\mathrm{GABA}_{\mathrm{A}}$ receptors, which exhibit rapid densitization even at moderate GABA concentrations (24).

Averaged dose-response data are plotted in Fig. $4 B$; for each determination, the response was normalized with respect to that obtained during superfusion with $10 \mathrm{mM} \mathrm{GABA}$. The curve through the data points is the Michaelis-Menten function with a Hill coefficient of 1 and an apparent $K_{\mathrm{m}}$ of $\approx 110 \mu \mathrm{M}$.

\section{DISCUSSION}

The results of the present study provide strong evidence that the GABA-induced currents in external horizontal cells of the skate retina represent an electrogenic uptake mechanism. Several findings support this view. (i) The responses to GABA were not mimicked by the $\mathrm{GABA}_{\mathrm{A}}$ agonist muscimol or the $\mathrm{GABA}_{\mathrm{B}}$ agonist baclofen, nor were the responses blocked by the usual $\mathrm{GABA}_{\mathrm{A}}$ or $\mathrm{GABA}_{\mathrm{B}}$ antagonists. (ii) The responses were dependent upon extracellular sodium and chloride, ions required for the uptake of GABA by a variety of neuronal cells, including retinal horizontal cells (25). The inability of lithium to substitute for sodium under these
A
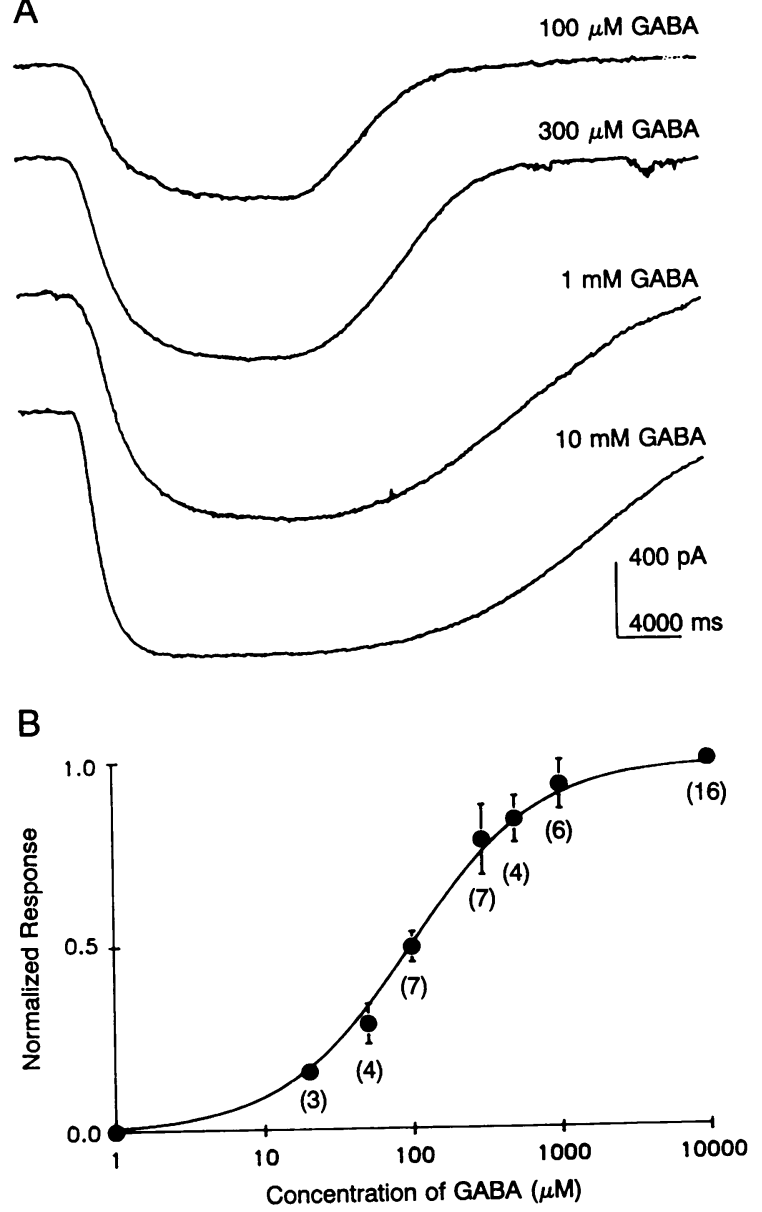

FIG. 4. Dose-response relationship for the GABA-induced current. (A) Responses from one cell to 10-sec applications of $100 \mu \mathrm{M}$, $300 \mu \mathrm{M}, 1 \mathrm{mM}$, and $10 \mathrm{mM}$ GABA (as indicated) applied by superfusion in the bath solution. $(B)$ Plot of the normalized response vs. GABA concentration. Typically, four concentrations of GABA were superfused in an ascending series over any given cell, one of which was always $10 \mathrm{mM}$ GABA; the currents obtained in response to the other concentrations were normalized to that obtained at 10 $\mathrm{mM}$. Numbers below data points reflect the number of cells examined at each concentration; error bars are standard deviations. The curve represents a Michaelis-Menten function fit with a Hill coefficient of 1 and a half-maximal response of $110 \mu \mathrm{M} \mathrm{GABA}$. Data were sampled every $25 \mathrm{msec}$.

circumstances is also noteworthy since this ion would be expected to permeate through sodium channels (26). (iii) Nipecotic acid, known to interact with uptake sites for GABA (27), produced a similar current and also reduced the response to GABA when applied concurrently.

The ability of nipecotic acid to block the effects of GABA has been reported (28) in studies utilizing intracellular recordings from horizontal cells in the intact carp retina. However, the application of nipecotic acid did not induce a depolarization of the horizontal cells; i.e., the drug appeared to act in a purely antagonistic manner in the carp retina. In skate, on the other hand, the large inward currents produced by nipecotic acid (Fig. 1) suggest that it may behave as a partial agonist for GABA transport, as it does in some other cell types (29).

The nature of the current-voltage relation provides further evidence that the GABA-induced inward current is mediated by activation of an electrogenic carrier, rather than by the gating of ion channels. Indeed, the current-voltage profile (Fig. $3 B$ ) resembles in some important respects that obtained for the glutamate-uptake carrier in Muller cells of the am- 
phibian retina (30). In both cases, the transmitter-mediated currents became progressively smaller as the cells were depolarized and, even at positive holding potentials, there was no evidence of reversal to an outward current. This is in contrast to previous findings concerning the actions of GABA on skate Muller cells (i.e., the glial responses to GABA reversed polarity near the chloride equilibrium potential), and the pharmacology indicated that the membrane currents were due to activation of $\mathrm{GABA}_{\mathrm{A}}$ receptors (23).

Our findings may appear to be at odds with the results cited earlier, indicating that in skate, uptake of radiolabeled GABA appears to be exclusively in Muller cells $(6,7)$. In situ, however, spatial considerations favor the accumulation of exogenously applied GABA by Muller cells. GABA must pass either the end feet of the Muller cells at the vitreal surface of the retina or the apical processes of the Muller cells at the distal face of the retina before it can diffuse to the horizontal cell bodies located in the outer nuclear layer. Thus, the ability of GABA to reach the horizontal cell layer may be greatly impaired by the activity of Muller cells. Furthermore, the typically low concentrations of tracer used in most autoradiographic studies ensures that uptake will be heavily weighted in favor of cells possessing a high-affinity uptake system (3). The data of Figs. $2 A$ and $B$ and $4 B$ indicate that skate horizontal cells carry out GABA transport by a sodium-dependent saturable uptake mechanism with relatively low affinity. The apparent $K_{\mathrm{m}}$ of $110 \mu \mathrm{M}$ is 5- to 50-fold higher than the values $(2-18 \mu \mathrm{M})$ typically reported for the high-affinity uptake systems of other cells $(31,32)$. If skate Muller cells possess an uptake system with a significantly higher affinity for GABA than that of the horizontal cells, this factor combined with the "barrier" effect described above may account for the inability to detect GABA uptake in horizontal cells by autoradiographic methods. It is noteworthy that the cellular pattern of GABA uptake is quite different in amphibia $(33,34)$, birds $(35)$, and other species of fish (36), none of which exhibit $\left[{ }^{3} \mathrm{H}\right] \mathrm{GABA}$ accumulation by glial cells. In teleost, for example, where GABA regulation has been studied most extensively, there is prominent labeling of cone-driven $\mathrm{H} 1$ horizontal cells, attributable to a single high-affinity uptake mechanism (31).

The finding that skate horizontal cells possess an apparently low-affinity transport system for GABA raises a question as to its physiological significance. In teleost, it has been suggested that the high-affinity uptake mechanism for GABA in $\mathrm{H} 1$ horizontal cells regulates both the uptake and release of the neurotransmitter; there is evidence that the release is largely calcium-independent, appears to depend upon sodium and voltage, and is blocked by nipecotic acid [refs. 37-40; see also Yazulla (1), for review]. Perhaps the low-affinity transporter of skate horizontal cells operates in a similar fashion but uses the carrier mainly to liberate GABA from the cells. Thus the sustained release of the photoreceptor's transmitter in darkness $(41,42)$ depolarizes the horizontal cell by increasing its conductance to cations (43). This may give rise to a sodium-dependent release of endogenous GABA and the activation, in turn, of GABA receptors on bipolar cells (9) (there is as yet no evidence of feedback from horizontal cells to skate rods). This hypothesis is consistent with the findings that skate horizontal cells contain both GABA and its synthetic enzyme $(4,5)$ and with the observation that the Muller cells provide an efficient uptake system for the removal of extracellular GABA $(6,7)$. Clearly, the present study was designed to examine only the uptake of GABA. Nevertheless, if the GABA transporter of skate horizontal cells does mediate the release of this transmitter, our results suggest that the balance between uptake and release is governed by a voltage- and sodium-dependent carrier mechanism that may have a number of features in common with that of teleosts.

We are grateful to Mr. Marek Mori for apparatus design and construction, to Mr. Haohua Qian for help with data analysis, and to Drs. Stephen Yazulla and David Pepperberg for helpful comments on an earlier draft of the manuscript. This study was supported by a grant (EY-06516) from the National Eye Institute and an unrestricted award to the Department of Ophthalmology from Research to Prevent Blindness, Inc. Portions of the research were conducted at the Marine Biology Laboratory, Woods Hole, during the tenure of a Grass Foundation Summer Fellowship to R.P.M.

1. Yazulla, S. (1986) in Progress in Retinal Research, eds. Osborne, N. \& Chader, G. (Pergamon, Oxford), Vol. 5, pp. 1-52.

2. Ehinger, B. \& Dowling, J. E. (1987) in Handbook of Chemical Neuroanatomy, Vol. 5: Integrated Systems of the CNS, Part I, eds. Bjorklund, A., Hokfelt, T. \& Swanson, L. W. (Elsevier, Amsterdam), pp. 389-446.

3. Martin, D. L. (1976) in GABA in Nervous System Function, eds. Roberts, E., Chase, T. N. \& Tower, D. B. (Raven, New York), pp. 347-386

4. Agardh, E., Bruun, A., Ehinger, B., Ekstrom, P., van Veen, T. \& Wu, J.-Y. (1987) J. Comp. Neurol. 258, 622-630.

5. Brunken, W. J., Witkovsky, P. \& Karten, H. J. (1986) J. Comp. Neurol. 243, 1-12.

6. Lam, D. M. K. (1975) Cold Spring Harbor Symp. Quant. Biol. 15, 571-580.

7. Bruun, A., Ehinger, B. \& Sytsma, V. M. (1984) Brain Res. 295, 233-248.

8. Cohen, J. L. (1988) Brain Res. 455, 366-369.

9. Lasater, E. M., Dowling, J. E. \& Ripps, H. (1984) J. Neurosci. 4, 1966-1975.

10. Malchow, R. P. (1989) Biol. Bull. 177, 324 (abstr.)

11. Malchow, R. P. \& Ripps, H. (1990) Invest. Ophthalmol. Visual Sci. 31, Suppl., 178 (abstr.).

12. Malchow, R. P., Qian, H., Ripps, H. \& Dowling, J. E. (1990) J. Gen. Physiol. 95, 177-198.

13. Hamill, O. P., Marty, A., Neher, E., Sakmann, B. \& Sigworth, F. J. (1981) Pflügers Arch. 391, 85-100.

14. Barker, J. L. \& Mathers, D. A. (1981) Science 212, 358-360

15. Hill, D. \& Bowery, N. G. (1981) Nature (London) 290, 149-152.

16. Krogsgaard-Larsen, P. \& Johnston, G. A. R. (1975) J. Neurochem. 25, 797-802.

17. Malchow, R. P., Qian, H. \& Ripps, H. (1989) Proc. Natl. Acad. Sci. USA 86, 4326-4330.

18. Barker, J. L., McBurney, R. N. \& Mathers, D. A. (1983) Br. J. Pharmacol. 80, 619-629.

19. Takeuchi, A. \& Takeuchi, N. (1969) J. Physiol. (London) 205, 377-391.

20. Dutar, P. \& Nicoll, R. A. (1988) Nature (London) 332, 156-158.

21. Kanner, B. I. \& Kifer, L. (1981) Biochemistry 20, 3354-3358.

22. Kanner, B. I. (1983) Biochim. Biophys. Acta 726, 293-316.

23. Qian, H., Malchow, R. P. \& Ripps, H. (1989) Invest. Ophthalmol. Visual Sci. 30, Suppl., 67, (abstr.).

24. Adams, P. R. \& Brown, D. A. (1975) J. Physiol. (London) 250, 85-120.

25. Yazulla, S. (1983) Brain Res. 275, 61-74.

26. Edwards, C. (1982) Neuroscience 6, 1335-1366.

27. Johnston, G. A., Krogsgaard-Larsen, P., Stephanson, A. L. \& Twitchin, B. (1976) J. Neurochem. 26, 1029-1032.

28. Kamermans, M. (1989) Ph.D. thesis (Univ. of Amsterdam, Rodopi Press, Amsterdam).

29. Althaus, J. S. \& Martin, D. L. (1989) Neurochem. Res. 14, 311-316.

30. Brew, H. \& Attwell, D. (1987) Nature (London) 327, 707-709.

31. Lam, D. M., Su, Y. Y. T., Chin, C. A., Brandon, C., Wu, J.-Y., Marc, R. E. \& Lasater, E. M. (1980) Brain Res. Bull. 5, 137-140.

32. Lam, D. M. \& Ayoub, G. S. (1983) Vision Res. 23, 433-444

33. Voaden, M., Marshail, J. \& Murani, N. (1974) Brain Res. 67, 115-132.

34. Pourcho, R. G., Goebel, D. J. \& McReynolds, J. S. (1984) Exp. Eye Res. $39,69-81$.

35. Marshall, J. \& Voaden, M. (1974) Invest. Ophthalmol. 13, 602-607.

36. Lam, D., Lasater, E. M. \& Naka, K.-I. (1978) Proc. Natl. Acad. Sci. USA 75, 6310-6313.

37. Schwartz, E. A. (1982) J. Physiol. (London) 323, 211-227.

38. Schwartz, E. A. (1987) Science 238, 350-355.

39. Yazulla, S. \& Kleinschmidt, J. (1983) Brain Res. 263, 63-75.

40. Ayoub, G. S. \& Lam, D. M. (1984) J. Physiol. (London) 355, 191-214.

41. Dowling, J. E. \& Ripps, H. (1973) Nature (London) 242, 101-103.

42. Ripps, H., Shakib, M. \& MacDonald, E. D. (1976) J. Cell Biol. 70, 86-96.

43. Shiells, R. A., Falk, G. \& Naghshineh, S. (1986) Proc. R. Soc. London Ser. $B$ 227, 121-135. 